\title{
Pemberdayaan PKK dengan Pemanfaatan Lahan Pekarangan untuk Mendukung Program Ketahanan Pangan Keluarga
}

\author{
Yeni Probowati \\ Universitas Wijaya Putra \\ yeniprobowati@uwp.ac.id
}

\begin{abstract}
Abstrak
Pemanfaatan lahan pekarangan menjadi obyek yang vital di masa pandemi ini. Lahan pekarangan yang tidak dimanfaatkan secara maksimal di Perumahan Pondok Benowo Indah RT 03 RW 08 Kelurahan Babat Jerawat seluas $200 \mathrm{~m} 2$. Salah satu penyebab dari terbengkalainya pekarangan tersebut adalah kurangnya kesadaran warga khususnya ibu PKK dalam memanfaatkan lahan pekarangan dengan tanaman yang bisa berfungsi sebagai lumbung hidup baik gizi maupun pangan serta tanaman apotik hidup. Kurangnya pengetahuan ibu PKK bahwa lahan pekarangan yang dimanfaatkan secara baik bisa berdampak ekologis serta dapat menambah pendapatan keluarga. Tujuan pengabdian ini agar masyarakat RT 03 RW 08 khusunya ibu-ibu PKK dapat mengelola, mengatur dan memanfaatkan lahan pekarangan disekitar rumah secara optimal. Terwujudnya program ketahanan pangan keluarga dari pemanfaatan lahan pekarangan serta meningkatkan pendapatan keluarga. Kegiatan pengabdian ini menggunakan metode Participatory Rural Apraisal (PRA). Adapun hasil dari kegiatan pengabdian ini adalah peningkatan kesadaran dan pengetahuan sumber daya manusia dalam hal ini ibu-ibu PKK RT 03 RW 08 dalam mengelola dan memanfaatkan lahan pekarangan, terwujudnya program ketahanan pangan keluarga dan meningkatkan kesejahteraan keluarga. Pengelolaan lahan pekarangan di RT 03 RW 08 berpotensi untuk meningkatkan nilai ekonomi keluarga dan konservasi lingkungan.
\end{abstract}

Kata Kunci: Pekarangan, PKK, Ketahanan Pangan Keluarga

\section{PENDAHULUAN}

Perumahan Pondok Benowo Indah RT 03 RW 8 berada di Kelurahan Babat Jerawat Kecamatan Pakal Kota Surabaya tepatnya wilayah Surabaya bagian barat. Menurut data statistik kota Surabaya luas wilayah RT 03 RW 8 PBI Babat Jerawat adalah $10.000 \mathrm{~m} 2$ dengan jumlah penduduk $56 \mathrm{KK}$ serta luas lahan yang tidak dimanfaatkan seluas $200 \quad \mathrm{~m} 2$. Berdasarkan survey, kegiatan masyarakat terutama ibu PKK dan dasawisma selain arisan dasawisma, arisan pkk, ada juga kegiatan pengajian wanita, posyandu dan sampah kering.
Untuk kegiatan yang bersifat produktif seperti pemanfaatan lahan kosong dengan tanaman yang produktif sangat minim. Pemanfaatan halaman pekarangan di RT 03 RW 08 lebih pada tanaman hias dan kurang nya pemahaman akan pentingnya tanaman toga dan sayur sebagai lumbung pangan dan tanaman obat keluarga yang mana sangat membantu dimasa pandemi ini.

Dewasa ini keberadaan pekarangan sudah mulai terdesak keberadaannya seiring dengan pertambahan jumlah penduduk. Pekarangan yang adapun banyak yang terbengkalai dan dibiarkan tanpa Pangan dan Kesehatan $\quad 463$ 
dimanfaatkan oleh pemiliknya padahal pekarangan mempunyai manfaat yang sangat besar. Bukan hanya manfaat ekologis tetapi pekarangan juga mempunyai peranan yang cukup penting dari sisi ekonomi. Pekarangan dapat berfungsi sebagai lumbung hidup, baik lumbung pangan maupun lumbung gizi dan sebagai apotik hidup (Madyowati, 2017)

Lahan pekarangan yang dikelola secara optimal dapat memberikan manfaat bagi rumah tangga dan keluarga yang mengelolanya. Hal ini dapat dilihat dari beragam fungsi dasar pekarangan yaitu warung hidup, bank hidup dan apotik hidup serta fungsi keindahan. Lahan pekarangan yang dikelola dengan baik dapat memberikan manfaat antara lain adanya peningkatan gizi keluarga, tambahan pendapatan keluarga, lingkungan rumah menjadi asri, teratur, indah dan nyaman yang dalam PKK disebut HATINYA PKK (Halaman Asri ,Teratur, Indah dan Nyaman), tercipta suasana keakraban dan keharmonisan antar keluarga serta sebagai sarana menambah ilmu pengetahuan dan keterampilan.Semakin beragam tanaman pangan atau tanaman obat keluarga (TOGA) yang dikembangkan serta semakin banyak ikan/ternak yang dibudidayakan, maka diharapkan keluarga/rumah tangga yang mengelola kehidupannya akan semakin sejahtera. Dan nantinya ketahanan pangan keluarga akan terwujud.

Anonim, (2011) menyatakan bahwa pekarangan merupakan tanah yang berada disekitar rumah dan jelas batas-batasnya.Oleh karena letaknya di sekitar rumah, maka pekarangan merupakan lahan yang mudah diusahakan oleh seluruh anggota keluarga dengan memanfaatkan waktu luang yang tersedia.

Pekarangan memiliki sejumlah peran dalam kehidupan sosial ekonomi rumah tangga. Menurut Sajogyo (1994), pekarangan sering disebut lumbung hidup, warung hidup atau apotik hidup. Disebut lumbung hidup karena sewaktu-waktu kebutuhan pangan pokok seperti jagung, ketela, serta umbi-umbian lainnya bisa disediakan di lahan pekarangan.Disebut sebagai warung hidup karena dalam pekarangan terdapat sayuran yang berguna untuk memenuhi kebutuhan konsumsi keluarga, dimana sebagian keluarga membelinya dengan uang tunai. Sementara disebut sebgai apotik hidup karena dalam pekarangan ditanami tanaman obat-obatan yang sangat bermanfaat dalam menyembuhkan penyakit secara tradisional.

Pekarangan di PBI kebanyakan di tanami dengan tanaman hias yang berfungsi untuk menambah keindahan dan kerindangan halaman rumah.Lahan pekarangan kurang di manfatkan secara maksimal untuk mendukung program ketahanan pangan di masa pandemi ini.Bisa dikatakan, pekarangan masih belum dimanfaatkan secara maksimal bahkan ada yang dibiarkan terbengkalai dan hanya ditumbuhi semak dan rerumputan. Kurangnya pemanfaatan lahan pekarangan ini disebabkan antara lain kurangnya pengetahuan dan ketrampilan dari pemilik pekarangan.

Selain itu permasalahan yang ada dan menjadi penyebab terbengkalainya lahan pekarangan adalah kurangnya kesadaran warga dalam mewujudkan tentang pentingnya HATINYA PKK. Keterbatasan dana untuk melakukan budidaya tanaman disekitar pekarangan juga menjadi kendala untuk mewujudkan HATINYA PKK karena masyarakat kurang kreatif dalam memanfaatkan lahan pekarangan dengan tanaman yang bermanfaat.

Program pengabdian kepada Masyarakat ini dilaksanakan dengan tujuan untuk memberdayakan ibu-ibu PKK RT 03 RW 08 dalam memanfaatkan lahan pekarangan Pangan dan Kesehatan 464 
dengan tanaman yang produktif dan bermanfaat untuk keluarga. Melalui progarm pemberdayaan masyarakat khususnya Ibu PKK dapat (a) memanfaatkan lahan kosong dengan tanaman sehat dan hijau sehingga terciptanya hatinya PKK (Halaman Asri Teratur Indah dan Nyaman ) (b) sebagai lumbung dan warung hidup serta apotik hidup sehingga meningkatkan derajat kesehatan, kelestarian lingkungan hidup serta membiasakan hidup sehat (c) Meningkatkan pendapatan keluarga dengan pemanfaatan toga (tanaman obat keluarga) sebagai minuman herbal(d) Terbentuknya kader ketahanan pangan keluarga (e) Menjaga konservasi lingkungan di wilayah RT 03 RW 08 Babat Jerawat Pakal Surabaya.

\section{METODE}

Terlaksana atau tidaknya suatu program kegiatan sangat ditentukan oleh bagaimana cara atu metode dari pelaksana untuk menyampaikan informasi kepada sasaran. Kegiatan pengabdian kepada masyarakat ini diawali dengan observasi untuk melihat respon dari masyarakat. Selanjutnya metode atau cara yang akan digunakan dalam pelaksanaan pengabdian kepada masyarakat kepada PKK PBI RT 03 RW 08 Babat Jerawat, Pakal Surabaya ini meliputi ceramah, diskusi, pelatihan juga pendampingan. Pelaksanaanmasing-masing metode yang dilakukandisesuaikan dengan permasalahan yangakandiselesaikan diwilayah pengabdian.

Untuk dapat meningkatkan manfaat pekarangan dari nilai konservasi metode yang dilakukan adalah dengan ceramah penyuluhan dan diskusi tentang pentingnya konservasi lingkungan. Pemanfaatan tanah pekarangan secara optimal merupakan salah satu upaya pelestarian dan peduli lingkungan. Selain itu masyarakat juga telah ikut andil dalam mencegah pemanasan global karena dapat mengurangi emisi karbon penyebab global warming sehingga lingkungan menjadi sehat dan bersih. (Lia, A. 2014)
Pemanfaatan tanah pekarangan dapat meningkatkan nilai ekonomi dan menambah pendapatan keluarga dengan menjual produkhasil pekarangan. Untuk dapat meningkatkan nilai ekonomi dari pemanfaatan pekarangan metode yang dilakukan adalah dengan penyuluhan dan pelatihan tentang teknik budidaya tanaman yang baik dan benar mulai dari persiapan media sampai panen. Menurut Arifin (2013) fungsi dasar pekarangan secara sosial ekonomis, yaitu produksi secara subsisten, dimana pekarangan dapat menghasilkan produksi untuk komersiil dan memberi tambahan pendapatan keluarga terutama di daerah yang mempunyai akses pasar yang baik

Produk pekarangan tersebut antara lain tanaman obat keluarga (TOGA) serta sayuran. Pemanfaatan tanah pekarangan menurut Ginting (1994) dapat dilihat dari kompleksitas tanamannya dan komoditas yang dihasilkan. Kompleksitas dan banyak produksi tersebut tergantung dari keanekaragaman usaha dankombinasi usaha dari petani (masyarakat). Usaha dari pemanfaatan lahan pekarangan dapat memberikan sumbangan rata-rata $49 \%$ dari pendapatan rumah tangga. Besar kecilnya kontribusi pekarangan terhadap pendapatan keluarga tergantung pada luas dan tingkat pemanfaatan lahan pekarangan tersebut.

Pemanfaatan tanah pekarangan merupakan salah satu alternatif sumber daya yang dapat digunakan untuk pemenuhan kebutuhan pangan. Lahan pekarangan terlalu sempit untuk dimanfaatkan sebagai lahan pertanian sawah, tetapi disisi lain masih banyak tanah pekarangan yang belum dimanfaatkan secara optimal untuk memenuhi kebutuhan pangan. Saat ini pekarangan pemnafaatannya masih terbatas pada tanaman hias sebagai penambah nilai estetika. Pemberian wawasan tentang pentingnya perwujudan HATINYA PKK untuk memenuhi kebutuhan pangan yang 
bergizi dan berimbang dalam suatu keluarga diberikan melalui ceramah dan diskusi. Pemanfaatan tanah pekarangan merupakan salah satu upaya untuk mengurangi kelangkaan pangan, Pemanfaatan tanah pekarangan dapat mendukung ketahanan pangan khususnya ketahan pangan keluarga melalui penanaman tanaman hortikultura seperti sayuran, bumbu-bumbu dapur, buahbuahan dan tanaman toga akan menjamin ketahanan pangankeluarga. Apalagi sayuran dan tanaman bumbu dapur seperti cabai,tomat merupakan bahan pokok yang dikonsumsi setiap hari.

\section{HASIL DAN PEMBAHASAN}

Sebelum tim pengabdian pada masyarakat melakukan kegiatan di lapangan, maka

pada tanggal 8 Juli 2020 terlebih dahulu dilakukan kegiatan studi pendahuluan (preliminary research dan observasi). ). Kegiatan ini dimaksudkan untuk mendapatkan informasi yang komprehensif tentang potret riil dan kondisi obyektif masyarakat yang akan menjadi sasaran program (subyek kegiatan) dan jugauntuk menggali permasalahan yang dihadapi masyarakat khususnya kelompok PKK, tanah pekarangan yang bisa dikembangkan, sumber daya yang ada, fasilitas sarana dan prasarana pendukung yang bisa dimanfaatkan. Selain itu observasi juga bertujuan untuk mengetahui

sejauhmana visibilitas program pemberdayaan PKK melalui pemanfaatan tanah pekarangan untuk mendukung perwujudan program pemerintah yaitu ketahan pangan keluarga.

Proses pelaksanaan studi pendahuluan dan observasi dilakukan dengan cara mengadakan komunikasi dan koordinasi dengan pihak-pihak stakeholders terkait yang akan terlibat dalam kegiatan ini baik secara langsung maupun tidak langsung antara lain Ketua RT 03 RW 08, Ketua dan pengurus tim penggerak PKK RT $03 \mathrm{RW}$ 08. Dari hasil obeservasi kemudian disusun langkah-langkah pelaksanaan program melalui beberapa tahapan yaitu penyuluhan, pelatihan dan praktek lapangan serta monitoring.

Anggota PKK adalah ibu-ibu penduduk RT 03 RW 08 yang pekerjaannya sebagian besar adalah ibu rumah tangga dan pekerja/wanita karir . Rata-rata usianya 30 tahun, namun ada 23 \%yang diatas usia produktif. Pendidikannya rata-rata yang lulus SLTA namun ada jugayang lulus Perguruan Tinggi (sarjana).

Peningkatan ketrampilan tentang pemanfaatan dan pengelolaan tanah pekarangan serta teknik budidaya tanaman yang benar diharapkan akan berdampak pada peningkatan kesejahteraan keluarga serta dapat mewujudkan dan melaksanakan program PKK.

Setelah dilakukan observasi kegiatan dilajutkan dengan penyuluhan tentang pemanfaatan pekarangan dan pelaksanaan program PKK.. Penyuluhan dilakukan pada tanggal 18 Juli 2020. Materi yang diberikan dalam penyuluhan adalah menanam harapan dan memupuk semangat di hati ibu PKK RT 03 RW 08 untuk berdaya guna ditengah pandemi ini. Selain itu memberi pengertian dan pemanfaatan pekarangan untuk mewujudkan ketahanan pangan keluarga. Selain penyuluhan juga dilakukan diskusi dengan tujuan untuk mengetahui tingkat pemahaman ibu-ibu anggota kelompok PKK dan memberikan kesempatan bagi anggotakelompok untuk bertanyaseluasluasnya tentang cara pemanfaatan tanah pekarangan dengan tanaman yang produktif.

Selama ini ibu-ibu anggota kelompok PKK RT 03 RW 08 belum sadar dan Pangan dan Kesehatan $\quad 466$ 
mengetahui serta memahami secara benar tentang pemanfaatan tanah pekarangan dan pelaksanaan, hal ini dapat dibuktikan pada saat diskusi anggota kelompok mengatakan bahwa selama ini mereka dalam memanfaatkan lahan pekarangan hanya asalasalan tanpa memperhatikan baik teknik maupun estetika.

Setelah kegiatan penyuluhan selanjutnya dilakukan praktek langsung tentang pemanfaatan tanah pekarangan untuk budidaya tanaman sayur dan toga pada tanggal 26 Juli 2020 . Praktek ini dilakukan di tanah pekarangan milik RT 03 RW 08 . Kemudian anggota kelompok PKK langsung dapat mempraktekan di tanah pekarangan masing-masing.

Pada saat dilakukan praktek anggota kelompok kelihatan sangat antusias untuk mengetahui bagaimana cara memanfaatkan tanah pekarangan secara optimal dengan budidaya tanaman yang baik dan benar serta mempunyai nilai estetika.

Kegiatan selanjutnya adalah memonitoring hasil kegiatan yang dilakukan pada tanggal 20 Agustus 2020 oleh tim pengabdi dan anggota kelompok yaitu dengan memantau keberhasilan anggota kelompok dalam memanfaatkan tanah pekarangan untuk budidaya berbagai jenis tanaman.

Hasil pelaksanaan kegiatan pengabdian ini menunjukkan indikasi sebagai berikut:

a. Peningkatan pengetahuan dan ketrampilan dalam memanfaatkan tanah pekarangan dan teknik budidaya tanaman serta program HATINYA PKK. Penyuluhan dan pelatihan ketrampilan tentang pemanfaatan tanah pekarangan serta

pekarangan dengan baik sehingga lingkungan dan halaman yang asri, teratur, indah dan nyaman dapat terwujud. Selain itu kebutuhan akan sayur dan bumbu dapur dengan standar kualitas tinggi, bergizi, dan aman dapat dicukupi oleh dirinya sendiri tanpa harus membeli dari luar sehingga dapat meningkatkan kesejahteraan dan perekonomian keluarga.

b. Peningkatan kebersihan dan kenyamanan lingkungan

Ibu-ibu anggota PKK telah memahami bahwa tanah pekarangan yang tidak dimanfaatkan serta dikelola dengan baik membuat lingkungan sekitar tempat tinggal menjadi terlihat kotor dan tidak nyaman serta tidak enak dilihat. Dengan kegiatan ini membantu meningkatkan pemahaman dan pengetahuan tentang pentingnya lingkungan serta halaman yang asri, teratur, indah dan nyaman sehingga dapat meningkatkan kesehatan keluarga untuk menjaga konservasi lingkungan dan mengurangi global warming

c. Terbentuknya kader ketahanan pangan keluarga

Ibu-ibu anggota PKK yang telah sadar akan pentingnya pemanfaatan lahan pekarangan dengan tanaman yang produktif nantinya akan terbentuk kader PKK dalam hal ketahanan pangan keluarga.

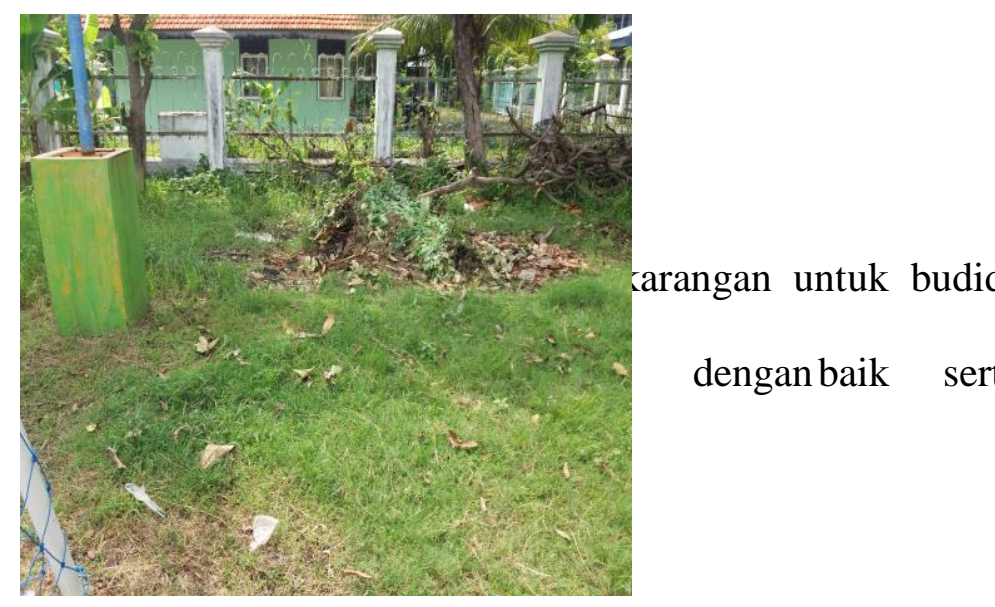


Gambar 1. Keadaan lahan pekarangan RT 03 RW 08 (Sebelum Program Pengabdian Kepada Masyarakat)

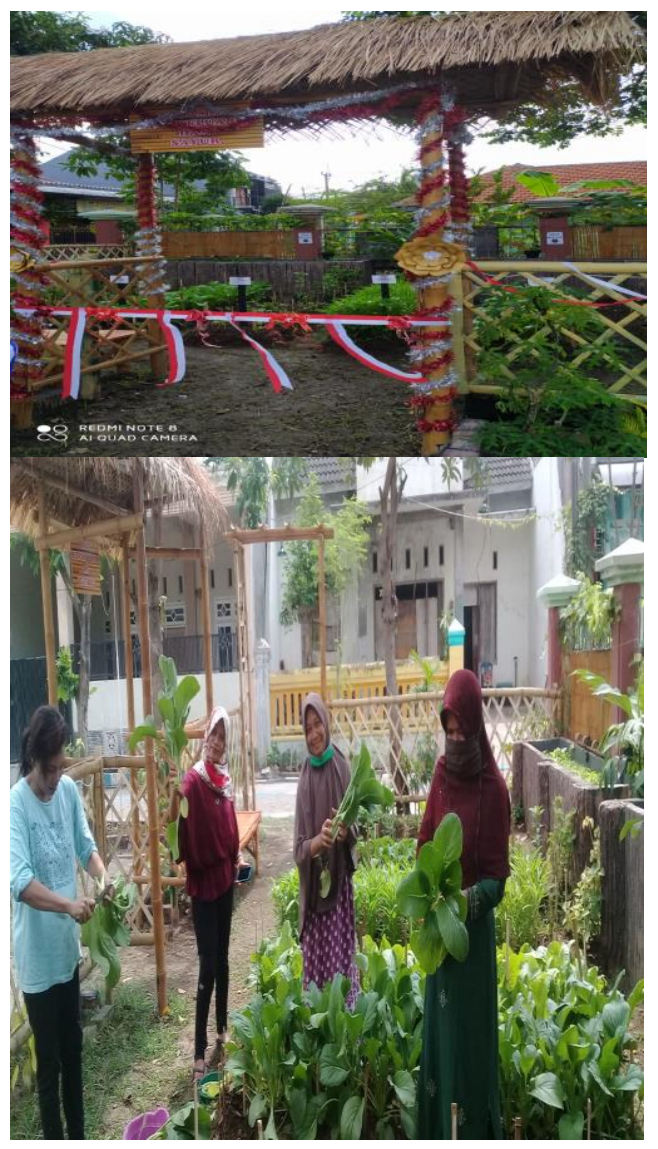

Gambar 2 : Keadaaan Lahan Pekarangan (Setelah Program Pengabdian Kepada Masyarakat )

Program kegiatan kepada masyarakat ini berpotensi untuk terus berkembang dan berkelanjutan seiring dengan situasi dan kondisi saat ini. Dalam situasi pandemi seperti ini, masyarakat khususnya ibu-ibu PKK diharapkan dapat meningkatkan ketrampilan dalam mengolah ketahanan pangan dan ekonomi keluarga. Melalui gerakan pemanfaatan lahan pekarangan ibu-ibu PKK RT 03 RW 08 dapat berkreasi di lahan pekarangannya masing-masing dengan berbagai macam varian tanaman yang produktif dan berguna. Metode penanaman nya juga bisa di variasi bisa melalui tabulapot (tanaman buah dan sayur dalam pot) atau melalui media hidroponik.

\section{KESIMPULAN}

Dari hasil kegiatan yang telah dilakukan maka dapat ditarik kesimpulan bahwa

kegiatan pengabdian kepada masyarakat ini sangat bermanfaat untuk menambah pengetahuan masyarakat khususnya anggota kelompok PKK RT 03 RW 08 dalam mengelola tanah pekarangan sehingga pelaksanaan program HATINYA PKK dapat terwujud. Dengan demikian pendapatan dan kesejahteraan keluarga juga akan meningkat seiring kebutuhan untuk pangan keluarga dapat terpenuhi dari hasil pekarangan sendiri serta program ketahanan pangan keluarga juga terwujud. Melalui program ini secara tidak langsung ikut menjaga kelestarian lingkungan melalui penanaman lahan pekarangan dengan tanaman penghijauan. Program ini diharapkan nantinya akan terus berkembang seiring dengan semakin meningkat kesadaran dan pemahaman ibu-ibu PKK serta dampak nyata dari pemanfaatan lahan pekarangan di wilayah RT 03 RW 08 dapat terlihat. Metode penanaman juga bisa dikembangkan lebih beragam melalui metode urban farming seperti tabulapot atau hidroponik. Lahan pekarangan tidak hanya ditanami tanaman yang produktif dan apotik hidup dengan sistem tumpang sari . Kedepannya lahan pekarangan di RT 03 RW 08 bisa di lengkapi dengan gazebo, internet gratis serta wahana permainan outbound bagi anak-anak sehingga bisa menghadirkan wisata alam mini ditengahtengah perumahan di dalam perkotaan.

\section{UCAPAN TERIMAKASIH}

Ucapan terimakasih disampaikan kepada 1) Ketua RT 03 RW 08 Perumahan Pondok 
Benowo Indah, 2) Kelompok PKK dan DasaWisma RT 03 RW 08 3) Universitas Wijaya Putra dan LPPM yang telah memberi bantuan materi dan dana untuk melaksanakan program Pengabdian kepada Masyarakat .

\section{REFERENSI}

Anonim, 2011. Rumah Hijau dalam Rangka Optimalisasi Pemanfaatan Pekarangan diPropinsi Jawa Timur. Dinas Pertanian Jatim.

Ariffin, Susilo H. 2013. Pekarangan Kampung untuk Konservasi Agribiodiversitas dalam mendukung keanekaragaman dan ketahanan pangan Indinesia. IPB Press, Bogor.

Ginting, 1994. Pekarangan petani, dan kemiskinan. Gadjah Mada University, Yogyakarta.

Lia Ameldalia. 2014. Pekarangan Rumah Sebagai Lingkungan Penyeimbang.

Madyowati, S.O, 2017. Sosialisasi Pengisian Buku Catatan Pemanfaatan Pekarangan/Hatinya PKK (Peternakan, Perikanan, Warung Hidup, Lumbung Hidup, TOGA, Tanaman Keras. Universitas Dr Sutomo. Surabaya.
Sajogyo .1994. Menuju Gizi baik Yang Merata di Pedesaan dan Di Kota . Gajah Mada Press. Yogyakarta

Tri Kusumastuti C dan Darsono. 2019. Pemberdayaan PKK Dengan Pemanfaatan Tanah Pekarangan Mendukung Perwujudan Hatinya PKK. Jurnal Berdaya Mandiri. Vol 1 No 1 Tahun 2019 ISSN 26858398 